\title{
An investigation whether the deputy president of the African National Congress can be the successor to the president during the National Elective Conference
}

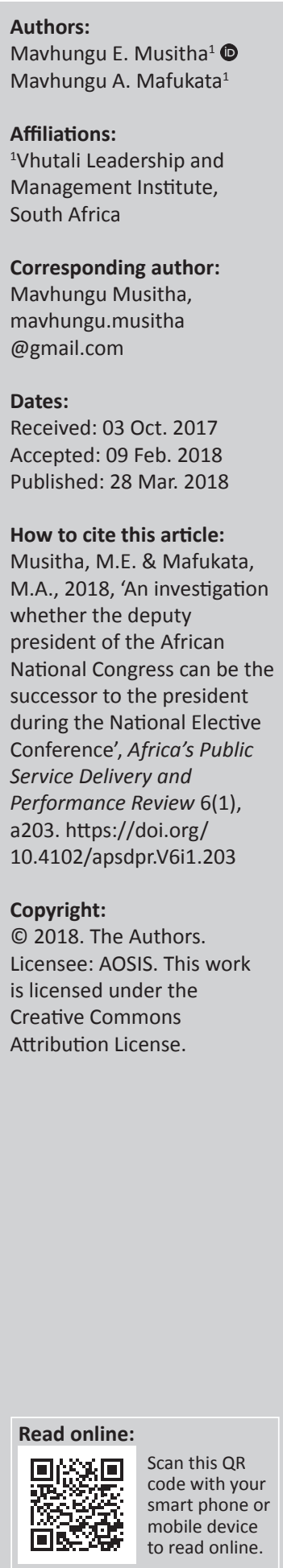

This is a qualitative study which investigated whether the deputy president of the African National Congress (ANC) can be the heir and elected president in the December 2017 elective conference. The study found that the deputy president is not the heir to the position of the president but that anybody can be elected to the position in terms of the existing constitution. The study also found that while the ANC has a constitution that prescribes how members are elected to positions, it is open to manipulation by those who wish to position their preferred comrades. The ANC does not have a clear policy or procedure to decide who succeeds to the presidency. This lack of policy has led to infighting among the comrades along factional lines as they seek to capture the soul of the ANC. The study found that most former liberation ruling parties such as ZANU-PF and the South West African People's Organisation are faced with the same challenge. The Chinese Communist Party has faced and overcome this challenge by formulating a clear policy and procedure on who becomes the president or leader of the party. The study recommends that the ANC should formulate clear policies and regulations to define and determine who becomes its president.

\section{Introduction}

The African National Congress (ANC) was faced with leadership succession battles as it prepared for the December 2017 elective conference. There are those who wanted the deputy president to become the president at this conference. There is also another group (or faction, as they are described) that wanted a woman to be elected president. The members and leadership of the ANC were unable to resolve this succession battle and this had the potential to tear the party apart. The faction that advocated for the deputy president to be the heir to the president argued that that is the policy or tradition of the ANC. There is a need to undertake a study that investigates whether the deputy president is the heir or not. At the centre of this succession battle is the question of what constitutes a policy or not. There is also confusion about what a tradition is or is not. There are some who think that a policy should be in writing while others are of the view that a policy does not necessarily have to be written. Those who argue that it does not have to be in writing contend that anything that is implemented over time without interruption constitutes a culture or a tradition which should be defined as a policy. It is on this premise that Motshekga (2017) contends that the culture and traditions of the ANC support Ramaphosa, who is the deputy president, as the 'heir to the throne'. President Mandela nominated Ramaphosa as his heir apparent in 1994 to succeed him when his term of office expired, but the proposal was opposed by those who favoured exiles to the throne (Munusamy 2012). According to Motshekga, those who oppose him today want to create confusion in the party. According to him, referring to the deputy president, the party must agree to 'elevate that person as a natural successor'. Motshekga (2017) further opines that 'the pecking order, unwritten as it is, says that the deputy succeeds the president unless there are grounds that disqualify him or her. We have a deputy that has a track record, who in terms of the culture and traditions should ascend...'.

However, the ANC adheres to its constitution in choosing its presidents, although it is preferable that deputies should be elected presidents. Rule 5 (5.1.4) of the Constitution of the ANC as amended at the 53rd National Conference, Mangaung 2012, declares that all members are eligible for election and to be elected. While most of the ANC deputies have ended up being elected as party presidents, it was not automatic, as they had to contest and win. Current President Zuma contested the position against the then President Mbeki while the former was deputy, in 2007 
at the Polokwane Conference. This is in agreement with the spirit of the constitution, whereby anybody can contest for the position instead of making it obvious. Celliers (2017) posits that the ANC has had 13 presidents, of whom only three were deputy presidents, and argues that Zuma had to be locked in a bitter contest with the then President Mbeki to wrestle the position from him. This then meant that Zuma succeeded Mbeki, himself having succeeded Nelson Mandela in 1997 without a contest. The other deputy who became president was Oliver Tambo. The author of this article therefore contends that it is certainly not obvious that deputies are the chosen heirs to the presidency. This article also contends that while there are those, such as Mantashe, who claim that it is a tradition for deputies to be heirs to presidency (Celliers 2017), such a claim cannot be scientifically substantiated. Yet, Saul, Chairperson of the Provincial ANC in the Northern Cape, cited in Phillips (2017), opines that at its 1949 National Conference, the ANC passed a resolution that preferred deputy presidents to ascend to the presidency and as such, according to him, this constituted an established tradition. Celliers (2017) points out that the ANC does not have a succession tradition and even if it had, it would be undemocratic because it would be contrary to the Constitution of the ANC. This article therefore explores the view that the ANC has a tradition of succession for deputies to become presidents. This study aims to provide answers to the political leadership challenge that the ANC was faced with. The ANC was caught in political mudslinging where 'dog eats dog' as opposing groups lobbied to capture the ANC at its elective conference in December 2017 during which the president of the party was elected. The ANC does not have a policy that guides its presidential succession process, so this article will provide a policy framework which its officials will consider for implementation in future to avoid a 'trial and error' approach. This article will propose a policy which will make it clear to all the members as to how to elect presidents from within its ranks.

\section{Context of the study 'brief profile of the ANC'}

The ANC is the former liberation movement in South Africa founded in 1912. According to its constitution as amended in 2012 at Mangaung, it was founded to defend and advance the rights of the African people after the violent destruction of their independence and the creation of a white supremacist Union of South Africa. Its fundamental goal is to construct a united, non-racial, non-sexist, democratic and prosperous society in South Africa. The ANC became the ruling party in 1994 at the demise of the colonial apartheid system. Section 3 (3.4) of its constitution as amended in 2012 at Mangaung defines it as democratic, non-racial and non-sexist and opposed to any form of racial, tribal or ethnic exclusivism or chauvinism. Sub-section 3.5 commits the ANC to support the emancipation of women, combat sexism and ensure that the voice of women is fully heard in the organisation and that women are properly represented at all levels. Rule 5 (5.1.4) accords members the right to take part in elections and also to be elected or appointed to any committee, structure, commission or delegation of the ANC. The ANC is led by six officials and ordinary members who make up the National Executive Committee (NEC) of some 80 members. The officials are the president, deputy president, secretary general, deputy secretary general, treasurer and chairperson. Every five years, the ANC convenes a conference to elect a new leadership. Since its unbanning in 1990, it has had five deputies. From 1991 to 1994 Walter Sisulu was the deputy president. Thabo Mbeki who subsequently became president took over from 1994 to 1997. Jacob Zuma was elected to the position in 1997 and in 2007 was elected president. In 2007, Kgalema Motlanthe was elected to the position until 2012 when he contested the position of president and lost to Zuma. Ramaphosa is the current deputy president, elected in 2012. Of these deputies, Mbeki and Zuma emerged as presidents of the party. Ramaphosa, the deputy president, was elected president in the December 2017 conference.

\section{Problem statement}

The ANC is faced with the challenge of leadership succession because the criteria for the succession to the presidency are ill-defined. Members (or comrades) of the ANC define the criteria as and when it suits them. If they favour the candidate, they apply another criterion. For example, Motshekga (2017) posits that it is the ANC tradition or culture that deputy presidents should become president and that it does not have to be in writing. Mantashe in the Mail and Guardian (2017) corroborating this view, argues that those who want a woman president should ensure that a woman is appointed as deputy president, otherwise the nation would demand why the deputy cannot become the president. In his own words, 'If a sitting deputy president cannot take over from the incumbent, the organisation is owed an explanation'. However, Celliers (2017) counters this argument by postulating that as much as many may wish to see the deputy president ascend to the presidency, relying on the ANC 'tradition' to do so is to ask a bit too much. On this view, Celliers (2017) is supported by Mahumapelo (2017), who posits that any suggestion that the deputy president should be viewed as a 'natural successor' is both simplistic and unconstitutional, since the Constitution of the ANC requires that anyone can be elected president. The whole National Conference is bedevilled by these two opposing views of tradition. Adekeye and Abdulrauf (2017) posit that these two views and those who hold them cannot be reconciled because they are motivated by their own individual selfish interests. This dilemma will haunt the ANC for a long time to come unless a study is undertaken to propose criteria or a policy to be adopted by the ANC to determine future presidential candidates. This study is intended to do so.

\section{Objectives}

The threefold objectives of this study are to:

- analyse the normative constitutional framework of the ANC to guide the election procedure 
- examine how other ruling parties (China, Zimbabwe and Namibia) elected leaders to become presidents

- propose policies to guide the ANC in electing its future presidents.

\section{Conceptual framework}

A conceptual framework is provided in this study as the dominant issues centre around tradition and policy. The purpose of the whole study is to examine whether a particular action taken by the ANC constitutes a policy or a tradition. The conceptual framework will enable the authors to come up with balanced findings and recommendations for the course the ANC should adopt to address its political problems. The debate is about the status of an heir in relation to the succession to the presidency. The question that must be raised in this article is, what does an heir mean? Wikipedia (2017) defines an heir as anyone who is first in line of succession to a position. Similarly, the English Oxford Living Dictionary (n.d.) views an heir as someone who is legally entitled to the property or a rank of another on that person's death and who continues the work of the predecessor. Historically, the term has been applied to hereditary titles, but metaphorically it is used to indicate one who has been anointed to succeed to any position of power such as a political or corporate leader. The ANC does not have any clearly-defined policies to elect its presidents. To resolve any potential chaotic power struggle, organisations should develop statutes to determine who becomes president so that everybody knows who succeeds whom as president when the position becomes vacant (Wikipedia 2017). This section discusses tradition and policy to determine whether what some members allude to indeed constitutes a policy that the ANC can apply in future elections to the presidency.

\section{Tradition and culture as implicit organisational policy}

Graburn (2006:6) contrasts tradition with innovation. Horner (1990), cited in Graburn (2006:6), defines it as the process of a handing down from generation to generation, a passing on of something such as a custom, or thought process over time. But Rathje (2009:51) sees it as the expansion of a traditional and one-dimensional concept. Graburn opined that it is the process which takes place of which people are unaware but become aware once its continuity is threatened by various forces. Rathje (2009:8) links tradition with culture in that it creates a high level of internal uniformity within a social system. Welsch (1995:39), cited in Rathje (2009:37), contends that it is the traditional concept of culture which has become untenable. Both tradition and culture, as they interrelate, cohere and become resistant to any possible change (Rathje 2009:37). This study therefore adopts the definition of tradition as anything that is implemented over time, irrespective of whether it is written or not. The fact that it is implemented over time in a sustainable manner suggests that it is an unwritten policy. This definition will be applicable to gauge whether the suggestions and actions of ANC comrades are in accordance with tradition or not. However, from 1952, the ANC has had seven deputy presidents and of this only four, namely, Mandela, Mbeki, Zuma and Ramaphosa, have become presidents. This, therefore, does not constitute a tradition because there are five who did not become presidents. The deputy president is not the heir to the throne. In the current constitution, he or she can be regarded as a theoretical heir whose position is not guaranteed until elected in a democratic process at the coming elective conference.

\section{Policy as an intentional course of action}

It should be contended in advance that there is no consensus on a single definition of what a policy is. Anderson (2003) suggests that a policy is a relatively stable, purposive course of action to address a specific problem. The definition in this case goes beyond policy as a statement of intent, but rather what is actually implemented. Anderson (2003) contends that policy is not a decision but something that unfolds over a period of time. Policy in this definition is what is implemented or what people see happening following a specific action. This article suggests that a policy is an instrument or a tool used to achieve a specific object or a specific goal. Cochran and Malone (2014:3) postulate that policy is an overall framework within which actions to achieve specific goals are taken. Policies are designed to respond to any perceived political problem. However, individuals are constantly trying to shape policies through the mobilisation of interest groups, advocacy and political lobbying. From the discussions of definition by Anderson, it can be deduced that a policy is a means or a tool that has influenced decisions and continues to do so. But Cochran and Malone (2014:3) suggest that it is the source of any action or decision taken by any entity. However, Fox and Meyer (1996) contend that a policy is a guide to action that should be followed by individuals in an institution to deal with a specific matter in a consistent manner. The ANC should make a conscious decision to formulate a policy to regulate its leadership succession, as Anderson (2003) contends that policies do not formulate themselves but should be designed. Lenihan (2009) opines that policies are crucial for resolving problems and achieving public goals. It is clear from the definitions by various scholars that the ANC does not have any policy at the moment and as such it is also clear that it does not have a policy to determine leadership succession as claimed by other members of the ANC. What it has is only a constitution which is used as a guiding tool to determine election procedures. This cannot promote consistency, as alluded to by Fox and Meyer (1996:96). This study, therefore, does not find any scientific evidence that concludes that the ANC has a policy for succession as some members particularly those who advocate for the deputy president claim. In summary, this article will treat a policy as any visible framework that has produced results after its implementation.

\section{Is the deputy president heir to the presidency?}

In order to discuss this question, it is imperative to first shed light on the fact that since 1952, the ANC has had seven deputy presidents. Nelson Mandela was deputy from 1952 to 
1958, Oliver Tambo from 1958 to 1985, Nelson Mandela again from 1985 to 1991, Walter Sisulu from 1991 to 1994, Thabo Mbeki from 1994 to 1997, Jacob Zuma from 1997 to 2007, Kgalema Motlanthe from 2007 to 2012, and Cyril Ramaphosa from 2012 to the present (Wikipedia). Only four of these deputies, namely, Mandela, Mbeki, Zuma and Ramaphosa emerged as presidents of the ANC. The role of the deputy president is to deputise for the president and carry out the functions entrusted to him by the National Conference, the National General Council, the president and the NEC. This suggests that the office works closely with, and executes the tasks of, the Office of the President.

Currently, there are debates going on within the ANC about whether the deputy president should be heir to the presidency. These debates are informed by the fact that there is currently no provision for the automatic elevation of the deputy to the Office of the President. This lack of provision only became evident when the demand arose for the ANC to have a woman president at the next elective conference of the ANC in December 2017. Those who argue for the deputy president to become president suspect that those pushing for a woman president are influenced by ethnicity, because the current deputy president does not come from one of the big ethnic groups such as the Zulus or the Xhosas. According to them, those who are pushing a woman candidate are creating a political problem that threatens to tear the organisation apart. The ANC does not have a written document setting out the criteria for the choice of its presidents, even though the organisation is almost 105 years old. However, in 1990, after its unbanning by the apartheid government, it formally began electing its leadership in the country. Motshekga (2017) posits that the manner in which the ANC elected its presidents from 1990 onwards should be allowed to continue and should be regarded as a tradition. Motshekga (2017) opined that through this tradition, Nelson Mandela, who was deputy president, became president when Oliver Tambo stepped down in 1992. Mandela was succeeded by his deputy, Thabo Mbeki, in 1997. Mbeki was in turn succeeded in 2007 by his deputy, Jacob Zuma, who is expected to step down in 2017. This line of succession according to Motshekga is informed by a particular understanding that deputy presidents as discussed in this section become presidents when the incumbent's term of office expires. However, Zuma (2017a) contends that it has never been an ANC tradition that deputy presidents become presidents but that '[i]t was an accident of history'. Contrary to this, Cele (2017) argues that this is an unofficial tradition which has benefitted Zuma and that it must be considered an established tradition, even if not written down, because it is a common practice within the ANC. This is consistent with Anderson's view (2003) that a policy is not a decision but something that unfolds over a period of time. Mchunu (2017) posits that if a deputy president becomes president by coincidence to date as Zuma (2017a) argues, then the ANC should have another president through that tradition or coincidence in 2017.
Motshekga (2017) posits that any attempt to ignore the tradition would exacerbate the divisions that are threatening the ANC as the party prepares for the elective conference in December 2017. He had contended that Cyril Ramaphosa, who was the deputy president, should succeed President Zuma when his term of office in the ANC expires in December 2017. Motshekga (2017) opined that the deputy president of the ANC should be the person to succeed the president when he leaves office and that the position should not be contested. According to Motshekga, the ANC has a tradition sanctified over the years that deputy presidents have (always?) succeeded presidents. Contrary to the 'tradition' of electing its presidents from deputies, Zuma contends that in fact South Africa is ready for a woman president and while speaking to radio listeners, Zuma (2017b) contended that Nkosazana Dlamini-Zuma, his former wife, had the necessary credentials for that position. He added that those who advocate for deputies to become presidents were abusing the ANC tradition of nominating their own candidate.

Motshekga, a trained lawyer who possesses a doctorate in Law, is aware of the gap in the Constitution. In the absence of a constitutional provision, the only tool according to Motshekga (2017) is to follow tradition that the organisation has followed over the years and which has largely kept the party together. Despite Zuma's claim, Motshekga (2017) contends that Ramaphosa 'is the only candidate fit to lead the ruling party'.

\section{Can the ANC make history by electing a woman president?}

The failure of the Constitution of the ANC for not having procedures for electing presidents has created an opportunity for a group within itself who want to elect a woman to be president. This group does not recognise the common tradition as posited by Cele (2017) that the deputy president should become the president. Those who lobby for a woman president argue that the ANC Constitution provides that 'all members are equal and can be elected to any position within the party'. Mahumapelo (2017:2) contends that the push for the election of Dr Nkosazana Dlamini-Zuma who is a woman candidate is époch making. Mahumapelo (2017:2) opined that the ANC has been in existence for 105 years and that in its history has never had a woman president. Similarly, Olumide, Kingsley and Akinlolu (2017:17) in their study in Nigeria found that there were invisible barriers or 'glass ceilings' in political parties that prevent women from advancing to higher office such as becoming presidents. Mahumapelo (2017:2) demands that the ANC, in building a non-sexist society, should begin by removing discrimination against women and that a woman should be elected president during the 2017 elective conference. Gasa (2017:16) notes that Zuma has argued that women are 'now ready for the position of presidency'. According to Gasa (2017:16), women had earlier confessed that they were not ready for 2017 but immediately Zuma replied that, on the contrary, they were ready, so then they changed their minds. The ANC Women's League (ANCWL) endorsed President Zuma's former wife, 
Dr Nkosazana Dlamini-Zuma (Van Staden 2017:6). Gasa (2017:16) suggests that the decision for a woman president and subsequent candidature could have been influenced in some quarters, quite possibly by President Zuma himself. Gasa (2017:16) further states that there are two other women candidates, namely, Baleka Mbete and Lindiwe Sisulu. This study will not, however, deal with these two other women candidates, because at the moment they are not seriously under consideration to make the final list. Ramaphosa and Dr Dlamini-Zuma are the likely candidates to face each other as they have received the most nominations by the South African Communist Party (SACP), the Congress of South African Trade Union (COSATU), the Women's League and the Youth League. If the December Conference had elected Dr Dlamini-Zuma, the ANC would have been seen as a democratic organisation that does not see leaders in terms of gender but of leadership and this would truly have been an epoch-making event as Mahumapelo (2017) suggested.

\section{The ANC Constitution and succession plan}

The activities of the ANC are regulated by its constitution which is amended and adopted every five years at a conference. The constitution was last amended in Mangaung in 2012. This constitution regulates all leadership election procedures in the ANC. Since the ANC is regulated in its operations and functions by a constitution, it is important to make the case for this constitution in relation to the election of office bearers including the president. The argument by Zuma that it is not the policy of the ANC for a deputy to become president is consistent with the Constitution of the ANC. Rule 5 (5.1.4) states that any member of the ANC has the right to take part in elections and be elected or appointed to any committee, structure, commission or delegation of the ANC. Mahumapelo (2017) posits that any suggestions that the deputy president should be viewed as a 'natural successor' is both simplistic and unconstitutional since the Constitution of the ANC requires that anyone can be elected president. However, Motshekga (2017) argues that in the absence of the constitutional provision or policy, the ANC should turn to tradition as it was the tool that has been used for deputy presidents to become presidents since 1990 when the ANC was unbanned. Mahumapelo (2017) further contends that suggesting that the deputy should automatically become president is tantamount to flouting the Constitution of the ANC. The motives not to support the deputy from becoming president could be construed as tribal or ethnic mentioned by COSATU. The ANC Constitution section 5.2 (5.2.6) enjoins members to combat tribalism, chauvinism, sexism, religious and political intolerance or any other form of discrimination or chauvinism (African National Congress Constitution 2012). This constitution as is evidenced in the discussions has a gap which has rendered it vulnerable to various interpretations by any member and even those in society at large. These various interpretations suggest that not all members are clear about the provisions of the Constitution. If they were clear, every member would have the same understanding.
This is the reason why some senior members of the ANC, like Mahumapelo and Motshekga, among others, are not in agreement. The Constitution of the ANC does not clearly define the procedure whereby the deputy president becomes president. It only says all members in good standing are eligible to elect and be elected. Then the question can be raised - Why then do you elect the deputy if he or she is not earmarked to take over when the incumbent leaves office? The Chinese Communist Party (CCP) has resolved this puzzle by developing procedures and policies on who becomes leader or president which have been used to overcome leadership challenges in the past. Accordingly, within the ANC, there is no one heir to the throne but anybody can be considered.

\section{Research methods and instruments}

This section provides a brief profile of the ANC, the research design and methods used in data collection.

\section{Research design}

Research design is viewed as a road map that the researcher decides to follow when he carries out a study. It is aimed at responding to the research questions as accurately, objectively and economically as possible (Kumar 2014:122). Two main research designs, namely, qualitative and quantitative, are provided (Kumar 2014:131). While the quantitative design is based on the philosophical doctrine of logical positivism (Wellman, Kruger \& Mitchell 2005:6), this is a qualitative study that is exploratory and descriptive with a view to providing more information and background for the reader (Kumar 2014:6).

\section{Methods used in data collection}

In research, there are two main sources of data, namely, primary and secondary (Adams et al. 2007:85). Primary data refer to data derived from respondents, while secondary data are derived from readily available sources (Adams et al. 2007:85). Secondary data are associated with qualitative studies and is therefore also utilised in this study. Data are also derived from books, journal articles, newspaper articles, historical material and websites.

\section{Review of literature}

'I have to be prevented at all costs from ascending to the position of President of the ANC. Some have even said it will happen over their dead bodies. I have not committed any crimes, I have not stolen any money, I have not looted state resources. But I am being targeted and smeared.' (Cyril Ramaphosa in Sunday Times 2017).

This quotation suggests that Deputy President Ramaphosa felt that he is the rightful heir to the presidency but there are forces within the ANC who, instead of backing him, are backing an alternative candidate. According to Hartley (2017:191), Ramaphosa is being targeted because he is the man 
who would hold those suspected of having led to the capture of South Africa, the so-called state capture accountable. However, contrary to this argument, Zikalala, cited in Mthethwa (2017), contends that KwaZulu-Natal could not support the notion that the deputy president implied that he was the automatic successor to the presidency. He concurs with the view of Celliers (2017), who argued that nominating a deputy president without democratic processes would be undemocratic. Hartley (2017) posited that Ramaphosa was not involved in state capture that has rocked South Africa of late. When Zuma appointed Ramaphosa to be his deputy in government, it created an impression to the party members that 'the deputy president was the person anointed to succeed the president' (Hartley 2017:148). Then President Zuma instead moved to endorse his former wife Dr Nkosazana Dlamini-Zuma (Hartley 2017:183). Failure to endorse his deputy as the future president but endorse his former wife instead led to the crisis for the succession to the presidency at the ANC National Conference in December 2017. The question that should be asked here is: How did other political parties achieve unity in the face of factional tendencies in managing the succession to the presidency? This section will attempt to answer this question.

Forde (n.d.) posits that in the face of leadership challenges, the CCP embarked on a method of establishing institutional processes of succession. This was a normative institutionalised process that sought to regulate both the behaviour of the individual members and also ensure certainty and stability in the leadership succession (Forde, n.d.:81). Consistent with this argument by Forde (n.d.), Habisso (2011) posits that most African countries do not have transparent, predictable and institutionalised succession strategies. Habisso (2011) however argues that there are some countries that are making progress, such as Botswana, Mali and Ghana, to mention but a few, who have adopted management strategies to facilitate legitimate paths to power. In the absence of clearly-defined succession procedures which oblige the holder of the office to step aside, tensions may arise when those who feel that they should be in line for succession threaten the security of the organisation (Rush 1974). However, Scobell, Tanner and Li (2001) argue that China evolved from a period where leaders chose or selected their successors as the 'heir presumptive' without necessarily involving the party. According to Scobell et al. (2001), this was the practice during the time when Mao and his successor Deng were in power. This article therefore contends that China once had leaders who anointed their own successors but then disputes and challenges arose and they then decided to establish institutional processes to regulate the succession of one leader to another. Political parties like the ANC should always bear in mind that without policies and regulation in place, there is a risk of power struggles breaking out between factions within the organisation (Forde, n.d.:83).

Zimbabwe is one country where ZANU-PF has two vicepresidents elected by the congress and they are placed in government with the understanding that the first vicepresident will succeed the incumbent, in this case, President
Mugabe. The Report by the Zimbabwe Human Rights (2014:6), however, shows that from Joshua Nkomo to Joice Mujuru and including Emerson Mnangagwa, Mugabe never anointed anyone to succeed him as he wanted to continue ruling both the party and state. His succession in the event that he was no longer in office would be settled by section 5.11 of the Draft Constitution of Zimbabwe (2012) that provides that one of the two vice-presidents should take over. Rush (1974) contends that the failure to manage succession and where the incumbent refuses to step down may tempt the successor to instigate action to assume leadership, which might in turn increase the incumbent's sense of insecurity and destabilise the government. Rush's suggestion was actually realised when First Vice-President Mnangagwa, whom Mugabe had dismissed two weeks earlier to thwart his ambitions to become president himself, connived with the army and confined Mugabe to house arrest whereupon he then assumed power himself in November 2017 (Cape Times 2017:10). This, therefore, suggests that institutional arrangements should be in place along with regulations for the succession and this cannot be left to chance. But in Zimbabwe, the decision of the president to nominate a successor raised the suspicion that he wished to establish a family dynasty headed by his wife who was known to cherish ambitions for the job (Ward 2015:2). This is consistent with the view of Hartley (2017) who contends that Ramaphosa's ascension was being blocked by the president who wants to anoint his former wife instead. However, this article contends that Deputy President Ramaphosa, who got elected in the December 2017 conference, was the preferred candidate. But the ANC still has to clearly define procedures and policies just like CCP has done to address the leadership succession because it has learnt lessons from its own experience of internal fighting for positions. But in Zimbabwe, ZANU-PF relied on its congresses to elect its leaders without any succession guidelines, thereby enabling Mugabe to retain power for as long as he wanted without giving way to one of his deputies to take over.

In Namibia, Samuel Nujoma became the President of South West African People's Organisation (SWAPO) in 1960. He led the Namibian War of Independence against South Africa from 1966. Nujoma had his preferred candidate Pohamba, his deputy president, to succeed him when he stepped down in October 2007. This was opposed by Foreign Minister Hidipo Hamutenya, who was dismissed because he was seen to be opposing President Nujoma (Melber 2015:55). Hamutenya broke away and formed a new opposition party, Rally for Democracy and Progress (Melber 2015:55). Pohamba went on to be elected unopposed as president at an elective party congress the following month. Deputy President Ramaphosa in the Sunday Times (2017) insinuated that by not promoting him as the next president, Zuma and his followers were trying to prevent him from becoming President of the ANC at its congress in December 2017. A candidate nominated by the president would undoubtedly receive a boost from other members of the party (Melber 2015:61). When Pohamba was re-elected for a second term in 2012, Geingob was re-elected as his deputy. In 2015, Geingob was elected state president and Pohamba was expected to carry on as the president of 
the party till 2017. He then unexpectedly resigned in 2015 and passed the torch to Geingob to act as president for the next two years before the congress could be held in 2017 (Melber 2015:61). Appointing Geingob to act as president for two years was to prepare him to be elected president of the party at the party congress two years later (Melber 2015:61). According to All Africa (2017), Geingob was subsequently elected, beating his two other candidates for the position. The process followed in Namibia in electing presidents was undemocratic because anyone who opposed it was victimised (Celliers 2017). This article therefore contends that SWAPO did not follow democratic procedures in electing its party presidents, but earmarked from the top those who were part of the exiles to lead the party (Melber 2015:63).

\section{Analysis}

\section{Analysing the normative constitutional framework of the ANC to guide the election procedure}

The Constitution of the ANC (2012) provides that all members of the ANC have the same rights, as long as they are in good standing. According to the rules, any such member is eligible to stand for election. This suggests that the ANC Constitution promotes internal democracy in relation to election processes. The case here is that of the deputy president whose supporters urged that he should ascend to the position when the current president would step down in December 2017 at the party election conference. Any deviation from the provisions of the Constitution is deemed undemocratic (Celliers 2017). But any deviation from democratic processes is influenced by circumstances. President Zuma was keen to see his former wife succeed him and sought justification in the Constitution and widespread acceptable of the empowerment of women at all levels (African National Congress Constitution 2012). But there were others such as Cele (2017) who argued that the deputy president is by tradition the heir to the presidency as previous deputies became presidents. This article contends that while some of the previous deputies did indeed become presidents, deputy president Motlanthe contested Zuma at Mangaung and failed. Zuma, in 2007, had to lock horns with President Mbeki to become president (Celliers 2017). Deputy President Ramaphosa ascended to the presidency as he beat other contenders at the congress and that should not be construed as a handover. This article further contends that the ANC should follow the example of the CCP which, after having experienced leadership challenges for decades, decided to develop clear procedures and policies to guide successions. The party should not rely on its constitution because there will always be competing interpretations every time the congress is convened.

\section{Examining how other ruling parties (China, Zimbabwe and Namibia) elected leaders as presidents}

The literature shows that liberation movements that became ruling parties had similar challenges in choosing presidents.
However, some, like China, did not allow the situation to threaten the party but instead formulated policies and procedures to deal with leadership challenges (Forde n.d.). According to Forde (n.d.), when faced with leadership challenges, the CCP established institutional processes of succession that sought to regulate both the behaviour of individual members and also ensure certainty and stability (Forde, n.d.:81). Scobell et al. (2001) argue that China evolved from a period where leaders chose or selected their successors as 'heirs presumptive' without necessarily involving the party. Zimbabwe has been faced with leadership challenges whereby vice-presidents were recycled without anyone becoming president because President Mugabe felt he was the only one entitled to rule the country (Ward 2015). Section 5.11 of the Draft Constitution of Zimbabwe (2012) provides that one of the two vice-presidents should take over in case the president vacates office. This lack of succession procedures and policies by the ruling party was the direct cause of the military takeover of the country which handed power to the dismissed First Vice-President Mnangagwa. In Namibia, presidents hand-picked their successors and imposed them on the members, and anyone who dared to challenge them was dismissed as was seen in the case of Hamutenya (Melber 2015). This was the case of Nujoma who picked Pohamba to succeed him. The party was split when Hamutenya was dismissed, so he formed an opposition party (Melber 2015). President Pohamba handed over the party presidency to Geingob in 2015 before his political term of office ended, thus leaving the remaining two years in the hands of Geingob to act till November 2017. This was clearly to position him so that he could consolidate his power which assisted him to win and become president (All Africa 2017).

\section{Proposed policies to guide the ANC in electing its future presidents}

It is clear that all African ruling parties have something in common. As evidenced by ZANU-PF and SWAPO in Zimbabwe and Namibia, parties there do not develop succession procedures to regulate the election of presidents. They rely on their party constitutions which provide democratic rights for all members who are equal and eligible for election. But this does not clearly and unambiguously state that deputy presidents are automatically heirs to the presidency. This therefore creates divisions in the parties as individual members seek to interpret the constitutions to suit themselves. In the case of ZANU-PF, vice-presidents were recycled and none was eventually elected to the position of president because the sitting president never vacated office until the army removed him in November 2017. SWAPO was bedevilled with political problems every time a new president was to be elected because the sitting president wanted to impose his preferred choice. When Pohamba was elected, a faction led by Hamutenya opposed the move which led to his dismissal. Geingob was also elected when his way was strategically paved by Pohamba who allowed him to first act as president in waiting for two years before an elective congress could be convened. When it did convene, it duly elected him. He was thus given an unfair advantage over 
his opponents. The CCP, having gone through leadership challenges where sitting presidents chose and imposed their preferred candidates (Scobell et al. 2001), had to come up with a normative institutionalised process to regulate both the behaviour of the individual members and also ensure certainty and stability in the leadership succession (Forde n.d.:81).

\section{Findings and discussions}

The literature has revealed that former political movements who become ruling parties do not formulate their constitutions in a manner which clearly spells out how their leaders, especially their presidents, are to be elected. Their constitutions, as was evidenced by ZANU-PF and SWAPO, are democratic in nature, but they are vulnerable to manipulation by individual members. The same applies to the ANC which guarantees equality to all members and the right to be eligible for election (African National Congress Constitution 2012). Zuma in Business Day (2017) denied that the ANC had a policy for a deputy to become a president. But by contrast, Mthembu in the New Age online (2017) threatened that, 'a crisis would befall the ruling party should President Jacob Zuma resist handing over leadership to his Deputy Cyril Ramaphosa'. ZANU-PF for decades faced leadership challenges because the incumbent was not prepared to relinquish power and allow the democratic process to elect his successor (Melber 2015). SWAPO also faced the same challenges where even when the constitution gave members the right to become leaders, they could not because each of the incumbents had his own preference. Nujoma preferred Pohamba and Pohamba preferred Geingob and all those preferred became presidents of SWAPO and also state presidents (Scobell et al. 2001). The CCP faced leadership challenges and so resolved to come up with procedures and principles to address them. The study found that polices take different forms, sometimes written, sometimes not. Anderson (2003) argued that a policy or tradition is any precedent or practice which has been implemented over time by organisations from generation to generation (Graburn 2006). Rathje (2009:51) suggested that the practice becomes almost identical with the traditional and one-dimensional concept of how the ANC elected its presidents in the past. But Rathjy (2009:51) also sees it as an expansion of the traditional and one-dimensional concept. The only problem is that ANC members might not have been aware that it was a tradition because at the time there was no object or action that threatened the continuity of the practice until today when the membership now realises that the candidate who is a deputy might not be their preferred choice (Graburn 2006). Welsch (1995:39), cited in Rathje (2009:37), argued that it has become a traditional concept of culture which has now become untenable. The debate about electing a woman President of the ANC is not an honest one, but Cochran and Malone (2014:3) argued that it is being promoted by individuals who are trying to shape policies by mobilising interest groups and by political lobbying. This explains why Zuma (2017a) contended that the accession of the deputy president to the presidency was 'a historical accident'. This study has found that the ANC has never devised a strategy to elect women to the presidency at any time during the 105 years of its history. According to Olumide et al. (2017:1), this is because of invisible barriers or ceilings that have prevented them. The desire to nominate a woman candidate is being seen as a strategy by those who hope to control her for their own selfish interests (Adekeye \& Abdulrauf 2017:1). The ANC should formulate policies that determine the succession to avoid a situation where anyone comes up with his own interpretation of how presidents should be elected. The Constitution of the ANC, while guaranteeing that everyone has the right to stand for election, should be amended at the coming conference to stipulate whether or not the deputy president is an heir to the presidency. The ANC should also hold workshops to inform its members, as it is clear that even some of its most senior officials such as Secretary General Mantashe and Chief Whip Mthembu do not understand the provisions of the ANC Constitution.

\section{Conclusions}

The ANC, like any other liberation movement, is facing leadership challenges that are evident in the manner in which comrades are approaching the December 2017 elective conference. It is clear that the factions within the party are positioning their preferred candidates to win. What makes the stakes so high is that the winner of this conference will become the state president if or when the ANC wins national elections in 2019 to continue as the governing party. It is clear from the literature and also from the Constitution of the ANC that the deputy president is not the sole heir to the presidency, but that any member in good standing of the ANC is eligible to contest in the presidential election at ANC. However, this is a recipe for the destruction of the party as the secretary general of the ANC has alluded to the fact that the organisation would need to explain why it did not elect its deputy as president. The CCP managed to overcome leadership challenges still faced by former liberation movements by formulating procedures to clearly identify who will be next in line to succeed to the top leadership when the incumbent's term of office expires. This procedure eliminated any guessing about who becomes the president and pre-empted the imposition of individual preferences. It is therefore clear that the ANC should adopt the approach of the CCP and formulate procedures and policies that guide its leadership succession, otherwise competing factions will tear the party apart.

\section{Acknowledgements}

The authors would like to acknowledge Mr Gareth Owen for editing the article before it could be submitted to the Journal for review. Finally, we would like to thank the peer reviewers and editors of this Journal for their professional work to improve the quality of this article to what it is now.

\section{Competing interests}

The authors declare that they have no financial or personal relationships which may have inappropriately influenced them in writing this article. 


\section{Authors' contributions}

M.E. conceptualised and drafted the framework of the article from its introduction to conclusion. M.A. was responsible for reading and providing quality assurance of the article. He also made some editing on the article to appeal better to a reader before it was sent to a professional editor.

\section{References}

Adams, J., Khan, H.T.A., Raeside, R. \& White, D., 2007, Research methods for graduate business and social science students, Sage, London.

Adekeye, M.A. \& Abdulrauf, A., 2017, 'Party primaries, candidate selection and intraparty conflict in Nigeria: PDP in perspective', International Journal of Politics and Good Governance 111(8.2), 1-36.

African National Congress Constitution (ANCC), 2012, As amended and adopted at the 53rd National Conference, Mangaung, Bloemfontein.

Africa News, 2017, Namibia's President Geingob elected leader of ruling SWAPO party, viewed 08 December 2017, from http://www.africanews.com/2017/11/27/ namibia-s-president-geingob-elected-leader-of-ruling-swapo-party//

All Africa, 2017, Namibia: Candidates for Swapo's top-four positions at 2017 party congress, viewed 08 December 2017, from http://allafrica.com/stories/ 201711230523.html

Anderson, J.E., 2003, Public policymaking: An introduction, Houghton Mifflin Company, Boston, MA, pp. 1-34.

Cape Times, 2017, 'Zim has a chance of a real rebirth', Cape Times, 24 November, Cape Town.

Cele, B., 2017, 'Zikalala attacks "ANC deserter" Ramaphosa', City Press, 06 August, pp. 1-14.

Celliers, C., 2017, 'No, Gwede, you are $77 \%$ wrong about the ANC's succession "tradition"', The Citizen, Sharing, pp. 1-16.

City Press, 2017, 'Mbete available to lead ANC, not "hurt" by ANCWL's backing of Dlamini- Zuma', City Press, 09 July, pp. 1-23.

Cochran, C.L. \& Malone, E.F., 2014, Public policy: Perspectives and choices, 5th edn., Lynne Rienner Publishers, Boulder, CO.

Dane, F., 1990, Research methods, Books/Cole Company, Wadsworth, OH.

Forde, B., n.d., 'Change at the top: Succession in the Chinese Communist Party', The ANU Undergraduate Research Journal 3, 81-95.

Fox, W. \& Meyer, I.H., 1996, Public administration dictionary, 3rd edn., Juta and Company Limited, Cape Town.

Gasa, N., 2017, 'Feminism is not on their radar', City Press, 16 July, pp. 1-13.

Graburn, N.H.H., 2006, 'What is tradition?', Museum Anthropology 24(2/3), 6-11, viewed 06 April 2017, from https://www.researchgate.net/publication/ 230505685

Habisso, T., 2011, 'The problematic of leadership succession in Africa: Why do leaders cling to power?', Tigrai Online, 08 June, pp. 1-6.

Hartley, R., 2017, Ramaphosa: The man who would be king, Jonathan Ball Publishers, Cape Town.
Kumar, R., 2014, Research methodology: A step by step guide for beginners, 4th edn., Sage, London.

Lenihan, D., 2009, Rethinking the public policy process: A public engagement framework, Public Policy Forum, Otawa, viewed 04 May 2017, from www. ppforum.ca

Mahumapelo, S., 2017, 'We are not voting cows', City Press, 16 July, pp. 1-16.

Mchunu, S., 2017, 'Zikalala attacks "ANC deserter" Ramaphosa', City Press, 06 August, pp. 1-24.

Melber, H., 2015, 'From Nujoma to Geingob: 25 Years of presidential democracy', Journal of Namibian Studies 18, 49-65.

Motshekga, M., 2017, 'Motshekga throws weight behind Ramaphosa campaign', Lecture delivered in Welkom, Staff News, 08 July, pp. 1-2.

Mthethwa, B., 2017, 'ANC KZN draws line in sand over their stance on party's leadership', Times Live.

Munusamy, R., 2012, In Daily Maverick. Cyril Ramaphosa: The return of Nelson Mandela's chosen one, Johannesburg, pp. 1-3, viewed 02 December 2018, from https://www.theguardian.com/world/2012/dec/20/cyril-ramaphosa-returnnelson-mandela

Olumide, A., Kingsley, O. \& Akinlolu, A., 2017, 'Political glass ceiling and the quest for Nigeria's first elected female governor', International Journal of Politics and Good Governance III(8.2), 1-20.

Phillips, B., 2017, 'Northern Cape Backs Ramaphosa', Politics, IOL News, 11 September, p. 1.

Rathje, S., 2009, 'The definition of culture: An application-oriented overhaul', Inter Culture Journal 8, 35-58.

Report of the Zimbabwean Human Rights NGO Forum, 2014, The moral remains: Succession and the ZANU PF Body Politic, Research and Advocacy Unit 231 S Facebook, Bulawayo.

Rush, M., 1974, How communist party states change their rulers, Cornell University Press, Ithaca, NY.

Scobell, A., Tanner, M.T. \& Li, C., 2001, China's political succession and its implications for the United States, Asia Program Special Report, viewed 12 July 2001, from http://www.wilsoncenter.org

Sunday Times, 2017, Ramaphosa speaks out: I'm not a blesser, but I did have an affair, viewed 08 December 2017, from https://www.timeslive.co.za/sunday-times/news/ 2017-09-02-ramaphosa-speaks-out-im-not-a-blesser-but-i-did-have-an-affair/

The Draft Constitution of Zimbabwe 18 July 2012 Incorporating Approved ZANU PF Amendments Veritas August 2012, Harare.

van Staden, G., 2017, 'In Sunday Times', Business Times, 06 July, viewed 06 August 2017, from www.businessalive.co.za

Ward, G.F., 2015, Political instability in Zimbabwe, Contingency Planning Memorandum No. 23, Centre for Preventive Action, Council on Foreign Relations, New York.

Wellman, C., Kruger, F. \& Mitchell, B., 2005, Research methodology, 3rd edn., Oxford University Press, Cape Town.

Wikipedia, Inheritance, viewed 19 August 2017, from https://en.wikipedia.org/wiki/ Inheritance

Wikipedia, 2017, History of the African National Congress, viewed 08 December 2017 from http://en.wikipedia.or/wiki/History_of_the_African_National_Congress

Zuma, G.J., 2017a, 'Not ANC policy for deputy to rise to president', Business Day, 13 January, pp. 1-2.

Zuma, G.J., 2017b, 'Zuma power deal doubts', The Star, 06 July, pp. 1-2. 